\title{
Takapyöräkonekylvön vaikutus satoon helposti liettyvillä mailla
}

\author{
Heikki Harmanen, Jussi Esala \\ SeAMK, Elintarvike ja maatalous, Ilmajoentie 525, 60800 Ilmajoki, etunimi.sukunimi@ seamk.fi
}

\section{TIIVISTELMÄ}

Viimevuosikymmeninä muokkaus- ja kylvökalusto ovat kehittyneet tehokkaimmiksi ja työvaiheet ovat vähentyneet. Valtamenetelmäksi on noussut kylvölannoitus takapyöräkoneella, jolla kylvettäessä siemenrivin tiivistäminen tapahtuu suuren osan koneen massasta kantavilla takapyörillä. Halusimme selvittää, lisääkö kylvötapa liettymis- ja kuorettumariskiä.

Maassamme on runsaasti helposti liettyviä ja kuorettuvia maita, joissa savespitoisuus on 15-40\%. Kyseiset maat ovat ruotsalaisluokittelun mukaan kevyt- ja keskisavia. Suomalaisen luokituksen mukaan kyseiset maalajit ovat lähinnä: $\mathrm{Hs}, \mathrm{He}, \mathrm{HHt}, \mathrm{HsS}, \mathrm{HeS}$ ja HtS maita. Ilmajoella suoritettiin kesinä 2013 ja 2014 kylvötapakoe. Maalaji oli suhteellisen helposti liettyvä mHHt, jossa on $27 \%$ Hs ja $12 \%$ S. Kokeessa selvitettiin eri vaiheessa tehdyn jyräyksen merkitystä ohrasadon määrään ja laatuun. Jyräys tehtiin Junkkarin Superseed takapyöräkylvökonella säiliöt puolillaan. Varsinainen kylvö tehtiin sivupyöräkoneella, jossa oli kylvörivin tiivistävä kapea jyräkiekko

Kokeessa oli molempina vuosina kolme koejäsentä, neljä kerrannetta jolloin tuli kaksitoista 0,125 ha ruutua. Kuhunkin ruutuun arvottiin kylvötavat, joita olivat: kylvö sivupyöräkoneella, kylvö sivupyöräkoneella + jyräys sekä kolmantena jyräys + kylvö. Koealat muokattiin joustopiikkiäkeellä 2-3 kertaa hienorakeiseksi. Kesäkuussa 2013 satoi reilut $90 \mathrm{~mm}$ ja maa liettyi voimakkaasti, mutta kuorettunut maa pysyi läpäisevänä. Kasvusto orastui tasaisesti (kylvö 23.5) ja satoerot olivat vähäisiä, keskisato oli 5612 $\mathrm{kg} / \mathrm{ha}$. Vuonna 2014 vähennettiin äestystä, koeruutujen etuosa äestettiin kuitenkin hienommaksi (koejäsen 13).

Keväällä 2014, (kylvö 23.5.) kesäkuun alun 8 mm sade lietti eniten jyräpyörän jäljille jäänyttä koejäsentä joka kuorettui kuivuessaan eniten. Kesäkuu jäi kuivaksi (sademäärä $22 \mathrm{~mm}$ ). Heinäkuun lopun sateissa vilja lakoutui. Jyrätyillä mailla versoutuminen oli heikompaa kuin jyräämättömällä ja kahteen kertaa äestetyllä osuudella heikointa. Kerran äestetyllä versojen lukumäärä oli suurin sivupyöräkonekylvöllä $587 \mathrm{kpl} / \mathrm{m}^{2}$ ja pienin kylvön jälkeen jyrätyllä $552 \mathrm{Kpl} / \mathrm{m}^{2}$. Kahteen kertaan äestetyillä vastaavat lukemat olivat $740 \mathrm{ja} 487 \mathrm{kpl} / \mathrm{m}^{2}$. Sivupyöräkylvölle kertaalleen äestetty oli ollut liian vähän, mutta jyrätyille sopivasti.

Kaikkien kertaalleen äestettyjen lohkojen keskisadoksi tuli $4965 \mathrm{~kg} / \mathrm{ha}$ (14\% kosteana). Hienommaksi äestetty koejäsen 13 antoi satoa $4677 \mathrm{~kg} / \mathrm{ha}$. Paras hehtaarisato ja hehtolitrapaino saatiin, kun pelkästään kylvettiin ilman jyräystä $5215 \mathrm{~kg} / \mathrm{ha}$, jyräys ennen kylvöä tuotti $4869 \mathrm{~kg} / \mathrm{ha}$ ja kylvön jälkeen tehty jyräys $4812 \mathrm{~kg} / \mathrm{ha}$. Vuonna 2014 vilja lakoontui heinäkuun rankkojen vesisateiden johdosta. Ilman lakoutumista satoerot olisivat todennäköisesti olleet vieläkin suuremmat. Hienoksi muokatun alueen sato jäi $583 \mathrm{~kg} / \mathrm{ha}$ pienemmäksi kuin kapeilla jyräkiekoilla varustetulla koneella kylvössä.

Helposti liettyvillä mailla takapyöräkoneella kylvön yhteydessä on syytä välttää liiallista muokkausta, koska jyräpyörät lisäävät liettymäriskiä rikkoessaan heikkorakenteisia muruja. Jälkiharalla voitaneen vähentää liettymisriskiä.

ASIASANAT Takapyöräkone, liettymä, kuorettuma, sato 


\section{Johdanto}

Suuri muutos kylvölannoituskoneen kehityksessä tapahtui, kun kylvölannoittimien sivukannatuspyörät korvattiin järeärakenteisella jyräpyörästöllä, kuljetusleveys kapeni ja työn tuotto tehostui koneiden työleveyden lisääntyessä ja jyräyksen yhdistyessä kylvölannoitukseen. Leveät traktorikuvioiset jyräpyörät tiivistävät maata siemen- ja lannoiterivien kohdalla. Tiivistys parantaa siemenen ja lannoitteen maakosketusta, josta on hyötyä varsinkin kuivina keväinä erityisesti poudanaroilla savimailla. Kevättöiden edelleen nopeutuessa jyräyksen merkitys muokkauksen ja kylvövirheiden korjaajana on vähentynyt. Kansankielessä puhutaan takapyöräkylvökoneesta tai lyhyemmin takapyöräkoneesta. Vakolan tiedotteessa nimeksi ehdotettiin jyräkylvölannoitin (Mikkola 1994).

Uusimman kylvömenetelmän soveltuvuutta helposti liettyville maille ei ole juurikaan tutkittu. Vuosittain maassamme kylvettävä vilja-ala on noin 1,3 miljoonaa hehtaaria (Satotilastot 2014). Suuri osa Pohjanmaan maista on herkästi liettyviä ja kuorettuvia keveitä kivennäismaita. Tässä kokeessa koekasvina on ohra, jonka viljelyala maassamme on 540 000ha. Huomattava osa Etelä-Pohjanmaan pelloista on helposti liettyviä ja kuorettuvia maita, joissa savespitoisuus on 15-40\%. Kyseiset maat ovat ruotsalaisluokittelun mukaan kevyt- ja keskisavia. Suomalaisen luokituksen mukaan kyseiset maalajit ovat lähinnä: $\mathrm{Hs}, \mathrm{He}, \mathrm{HHt}, \mathrm{HsS}, \mathrm{HeS}$ ja HtS maita.

Aiemmassa laajassa kirjallisuuskatsauksessa jyräyksestä todetaan olleen monilla maalajeilla hyötyä, mutta toisaalta myös liettymisriski on tiedostettu (Kara ym. 1973). Varsinkin hiesu on liettymälle ja kuorettumalle erityisen herkkä (Simojoki \& Sunio1979). Rypsin kolmivuotisissa jyräyskokeissa Ylistaron $\mathrm{HHt}$ ja HtS mailla, kylvön edellä tai sen jälkeen tehty jyräys on sekä lisännyt että alentanut satoa tai sillä ei ollut vaikutusta riippuen kevään olosuhteista. (Köylijärvi 1985). Pelkkä jyräpyörästö (kiekot) on lisännyt satoa (Köylijärvi 1985). Ylistaron tutkimusaseman HtS, HsS ja multamaiden jyräyskokeissa vuosina 1973-79 jyräys kannatti lähes aina ja varsinkin, jos kylvöaika on kuiva ja myöhäinen, toisaalta jyräys voi myös alentaa satoa, jos kylvetään märkään maahan ja jyrätään heti kylvön jälkeen (Esala \& Hautala 1981). Multamaalla kasvusto lakoisuus väheni sateisina vuosina kasvuston pysyessä tiiviissä maassa paremmin pystyssä (Esala \& Hautala 1981).

Takapyöräkonekylvön liettävä vaikutus on ollut käytännössä näkyvissä Pohjalaisilla pelloilla. Liettymisriski tuodaan esille myös Vakolan tiedotteessa 67/94 (Mikkola 1994) "Jyräkylvölannoittimella ei ole suositeltavaa ajaa jo kylvetylle osalle peltoa etenkään hiesuisilla mailla, koska pinta jauhautuu helposti liian hienoksi ja kovettuu pienenkin sateen jälkeen. Siksi on parempi kylvää edestakaisin ajaen kuin lohkon ympäri ajaen. Päisteet kylvetään lopuksi." Mikkolan (1995) mukaan jyräkylvölannoitin tiivistää maata enemmän kuin jyräpyörästö tai kamriikkijyrä. Aiemmat jyräyskokeet ovat erilaisten jyrien ja jyräpyörästöllä varustetun kylvön ja jyräämättömän kylvön kokeita.

Tutkimushypoteesina on, että takapyöräkoneen pyörät rikkovat helposti liettyvien kevyiden maiden muruja ja altistavat maan liettymiselle ja kuorettumiselle ja siten alentavat satoa.

\section{Aineisto ja menetelmät:}

Koe toteutettiin Ilmajoen koulutilan pelloilla vuosina 2013 ja 2014. Maalaji oli mHHt, savespitoisuus $12 \%$ ja hiesupitoisuus $27 \%$ (Harmanen 2007). Koekasvina oli ohra ja lannoitus tehtiin viljavuustutkimuksen perusteella tavoitellen $4000 \mathrm{~kg} / \mathrm{ha}$ satoa.

Koealueet olivat syksyllä kynnettyjä ja ne äestettiin joustopiikkiäkeellä keväällä 2013 2-3 kertaa hienorakeiseksi ja vuonna 2014 kertaalleen, jolloin maa jäi karkeammaksi, koeruutujen etuosa äestettiin kahteen kertaan hienommaksi. 
Koejäseniä oli molempina vuosina kolme, jotka olivat:

Pelkkä kylvö laahavantaisella sivupyöräkoneella, ei erillistä jyräystä

Jyräys takapyöräkoneella ja sen jälkeen kylvö edellä mainitulla sivupyöräkoneella

Kylvö edellä mainitulla sivupyöräkoneella ja jyräys takapyöräkoneella.

Jyräykset tehtiin koulun Junkkari Superseed S3000 takapyörä kylvökoneella säiliöt puolillaan. Kaikki kylvöt tehtiin yhtenevän kylvölannoituksen vuoksi vm. 1992 Tume kylvölanoittimella (tekniset tiedot: työleveys 2,5 m, kokonaisleveys 3,4 m, siemenriviväli $12,5 \mathrm{~cm}$ ja lannoiteriviväli $25 \mathrm{~cm}$ ) Koneessa on lisäksi kapeat jyräkiekot vantaiden jälkeen (painovoima n. $100 \mathrm{~N}$ ). (Superseedissä lannoite olisi mennyt siemenvantaiden kautta). Kerranneita oli 4 kappaletta. Kaikki ruudut olivat pinta-alaltaan 0,125 ha. Koejäsenet arvottiin kerranneisiin. Lohkoilla tehtiin tavanomaiset rikkakasviruiskutukset. V 2013 mitattiin maan kosteutta ja lämpötilaa. Tilastollinen analyysi tehtiin SPSS-ohjelmalla.

\section{Peltolohkojen puinti ja sadon punnitus}

Kasvustot puitiin vuonna 2013 30.8. ja vuonna 2014 2.9. Sampo Rosenlew 2045 puimurilla. Kaikki kaksitoista lohkoa sekä lisäksi kolmastoista lohko vuonna 2014 puitiin erikseen ja jokaisen koelohkon viljakuormasta otettiin kahden litran pussillinen viljaa talteen Kosteuden ja Hl painon määrittämistä varten. Koeruutusadon punnitus suoritettiin kuivurin vaa'alla. Kasvukausien sateet selviävät kuvista 1 ja 2.

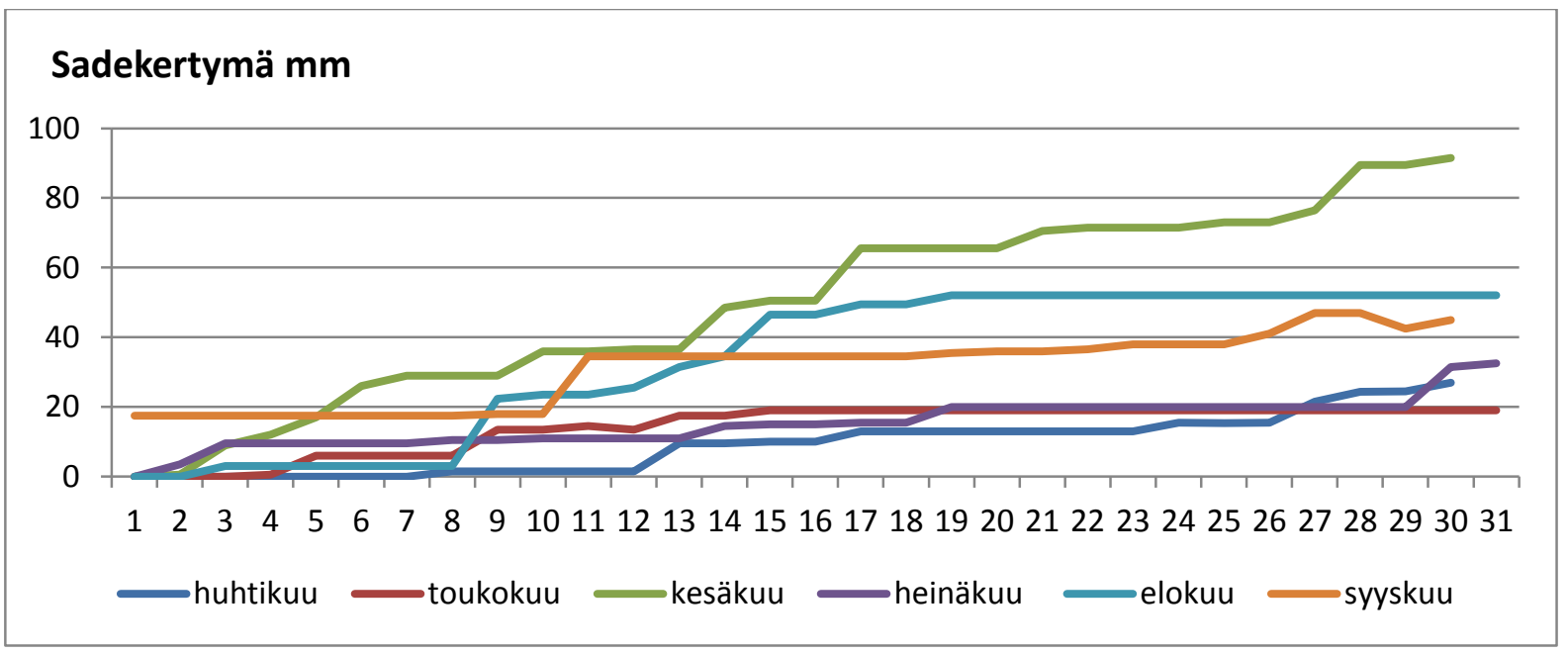

Kuva 1. Kesän 2013 sademäärät

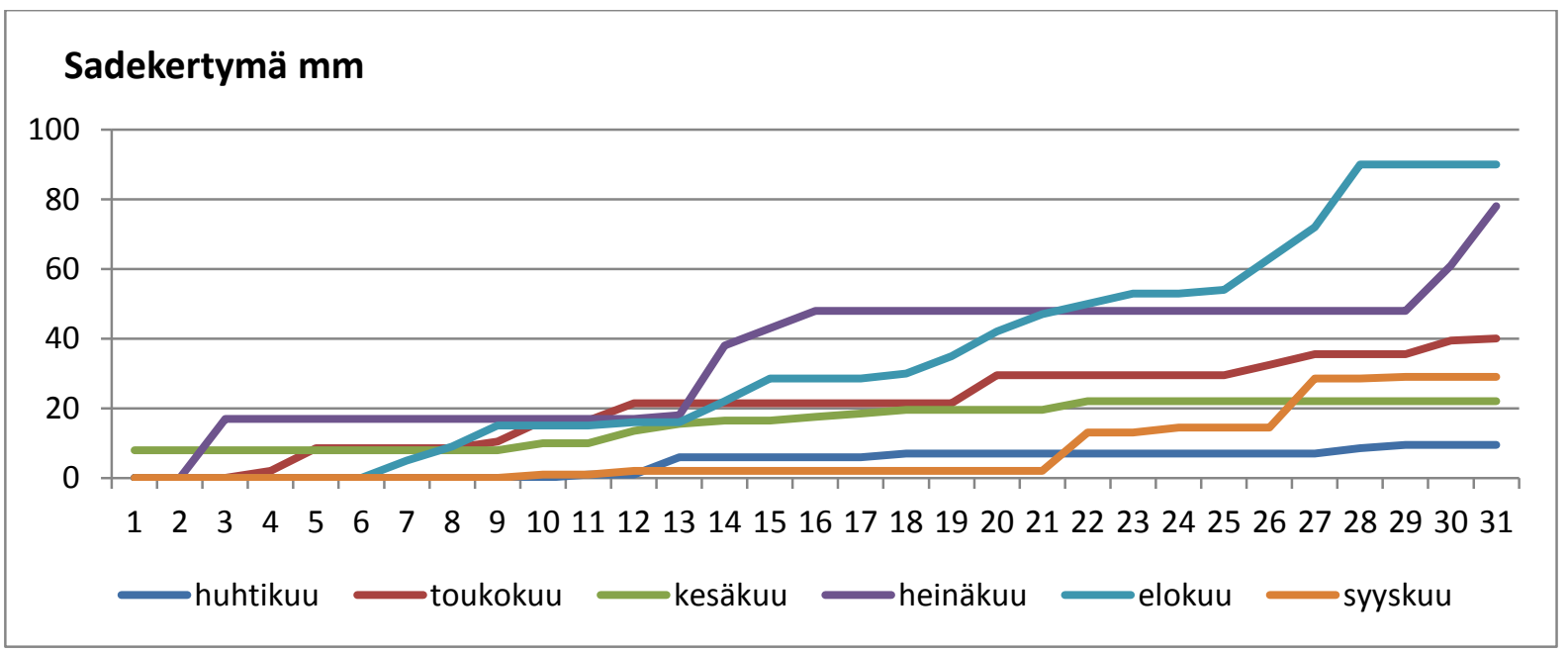

Kuva 2. Kesän 2014 sademäärät 


\section{Tulokset ja tulosten tarkastelu}

Keväällä 2013 maa oli kylvöhetkellä (24.5.) erittäin kuiva vähäisten sateiden vuoksi (kuva 1). Kasvustot orastuivat suhteellisen tasaisesti (kuva 3), kylvön jälkeen jyrätty koejäsen taimettui hieman muita koejäseniä hitaammin. Orastumisen jälkeen kesäkuun alun sateet, liettivät maata. Liettyminen oli silmämääräisesti tarkasteltuna runsainta jyräpyöräkoneen jäljiltä. Kesäkuun aikana tuli kuitenkin runsaasti ja tasaisesti vettä (reilu $90 \mathrm{~mm}$ ). Kasvustot versoutuivat tasaisesti. Sateen johdosta pellon pinta pysyi märkänä, liettynyt pellonpinta ei päässyt kuivumaan ja kuorettuma ei kovettunut. (kuva 4). Heinäkuu oli vähäsateinen, mutta vettä riitti maassa. Elo ja syyskuun sademäärä on ollut riittävän tasainen ja normaali hyvän kasvun saavuttamiseksi.

Koejäsenillä ei ollut satoeroja. Satotasoksi muodostui $5570-5640 \mathrm{~kg} / \mathrm{ha}$. Tulos oli samanlainen, kuin Vakolassa tehdyssä jyräyksen liettämiskokeessa, jossa liettävää sadetusta seurasi sadejakso, kuorettuma ei kuivanut kovaksi (Mikkola 1994). Maan pintakerroksen lämpötila oli kasvukauden alkupuolella hieman $\left(0,4^{\circ} \mathrm{C}\right)$ korkeampi jyrätyissä ruuduissa, maan kosteudessa ei ollut eroja (Hannula 2015). Totaalisen liettymisen seurauksena millään koejäsenellä ei ollut kapillaarisuutta ja katkaisevaa ja evapotraatiota estävää pinnan mururakennetta. Veden (ja ravinteiden) puute saattoi jossain määrin leikata satoja, hehtolitrapaino oli $60 \mathrm{~kg}$.

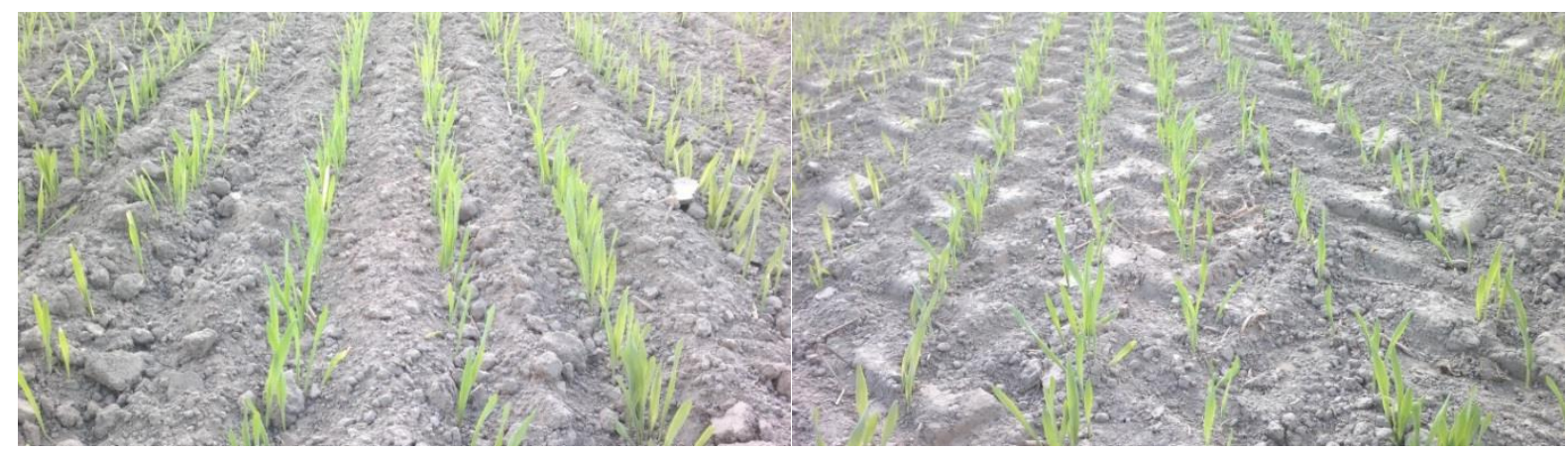

Kuva 3. Orastuminen tapahtui ennen liettymistä. Vasemmalla jyräämätön, oikealla jyrätty (Kuva 31.5. 2013)

Keväällä 2014,kylvö tehtiin 23.5. Taimettumisen jälkeinen, kesäkuun alun 8 mm sade lietti eniten jyräpyörän jäljille jäänyttä koejäsentä joka kuorettui kuivuessaan eniten. Kesäkuu jäi kuivaksi (sademäärä $22 \mathrm{~mm}$ ). Heinäkuun lopun sateissa vilja lakoutui. Elokuussa vettä tuli runsaasti (kuva 2), osin tähkäitänyt kasvusto saatiin kuitenkin puitua.

Jyrätyillä mailla versoutuminen oli heikompaa kuin jyräämättömällä ja kahteen kertaa äestetyllä osuudella heikointa. Kerran äestetyllä versojen lukumäärä oli (pääkasvuvaihe 21, versoutumisen alussa 12.6.) suurin sivupyöräkonekylvöllä $587 \mathrm{kpl} / \mathrm{m}^{2}$ ja pienin kylvön jälkeen jyrätyllä $552 \mathrm{Kpl} / \mathrm{m}^{2}$. Kahteen kertaan äestetyillä vastaavat lukemat olivat $740 \mathrm{ja} 487 \mathrm{kpl} / \mathrm{m}^{2}$. Sivupyöräkonekylvölle kertaäestys oli ollut liian vähän, mutta jyrätyille sopivasti.

Kaikkien kertaalleen äestettyjen lohkojen keskisadoksi tuli $4965 \mathrm{~kg} / \mathrm{ha}$ (14\% kosteus, taulukko 1). Hienommaksi äestetty koejäsen 13 antoi satoa $4677 \mathrm{~kg} / \mathrm{ha}$. Paras hehtaarisato ja hehtolitrapaino saatiin, kun pelkästään kylvettiin ilman jyräystä $5215 \mathrm{~kg} / \mathrm{ha}$, jyräys ennen kylvöä tuotti $4869 \mathrm{~kg} / \mathrm{ha} \mathrm{ja} \mathrm{kylvön} \mathrm{jälkeen}$ tehty jyräys $4812 \mathrm{~kg} / \mathrm{ha}$. Vuonna 2014 vilja lakoontui heinäkuun rankkojen vesisateiden johdosta. Osin tähkäitäneen kasvuston hehtolitrapaino jäi kaikilla koejäsenillä alhaiseksi ollen $51 \mathrm{~kg}$. Ilman lakoutumista satoerot olisivat todennäköisesti olleet vieläkin suuremmat. 
Taulukko 1. Ohran sato v. 2014 (kosteus $14 \%$ )

$\mathrm{K}=$ tavanomainen kylvö, $\mathrm{J}$ jyräys takapyöräkoneella joko ennen tai jälkeen kylvön.

\begin{tabular}{|c|c|c|c|c|c|}
\hline \multicolumn{6}{|c|}{ Kerranne } \\
\hline kylvötapa & 1 & 2 & 3 & 4 & keskiarvo \\
\hline K & 5445 & 5238 & 5124 & 5055 & 5216 \\
\hline $\mathrm{J}+\mathrm{K}$ & 4538 & 4828 & 5073 & 5036 & 4869 \\
\hline $\mathrm{K}+\mathrm{J}$ & 4804 & 4542 & 4840 & 5061 & 4812 \\
\hline & 4929 & 4869 & 5012 & 5051 & 4965 \\
\hline
\end{tabular}

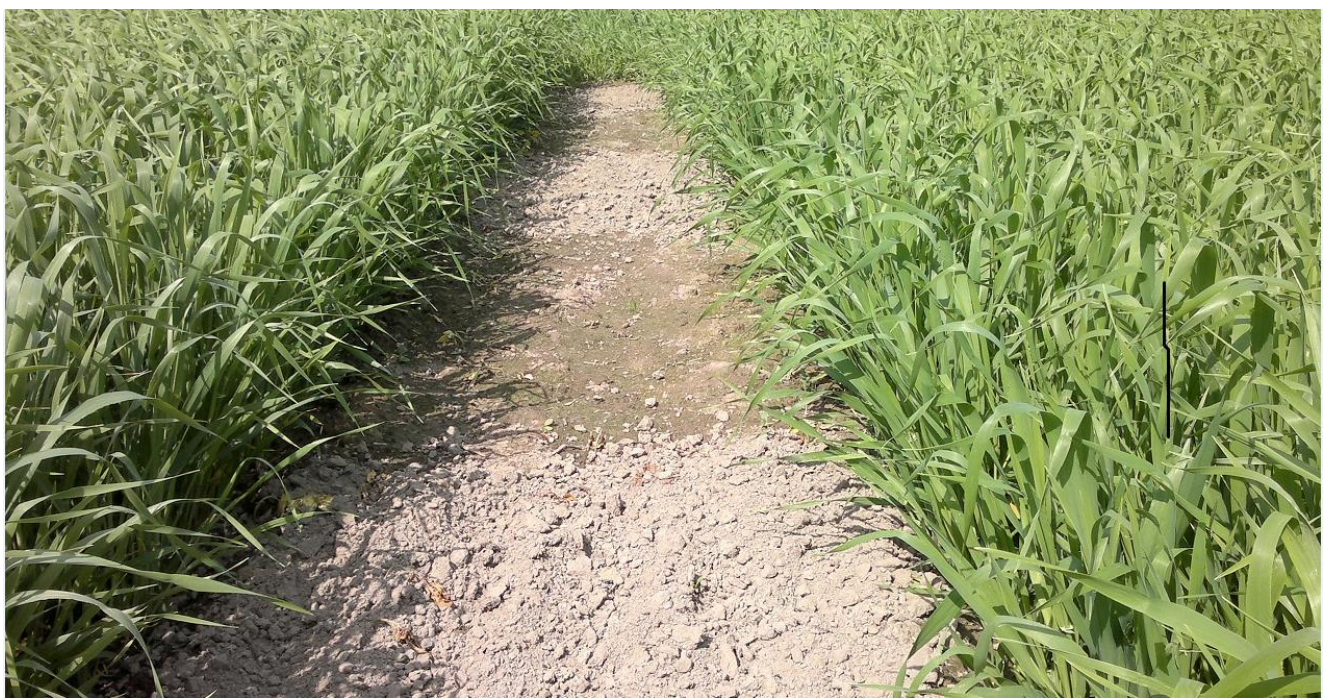

Kuva 4. Vuoden 2013 liettynyt ja kuorettunut kerranneväli. Testiharaus katkaisee kapillaarisuuden. Kuorettuma ei kovettunut sateisena kesäkuuna, joten orastuminen ja versoutuminen oli normaalia. (Kuva otettu 26.6.2013)

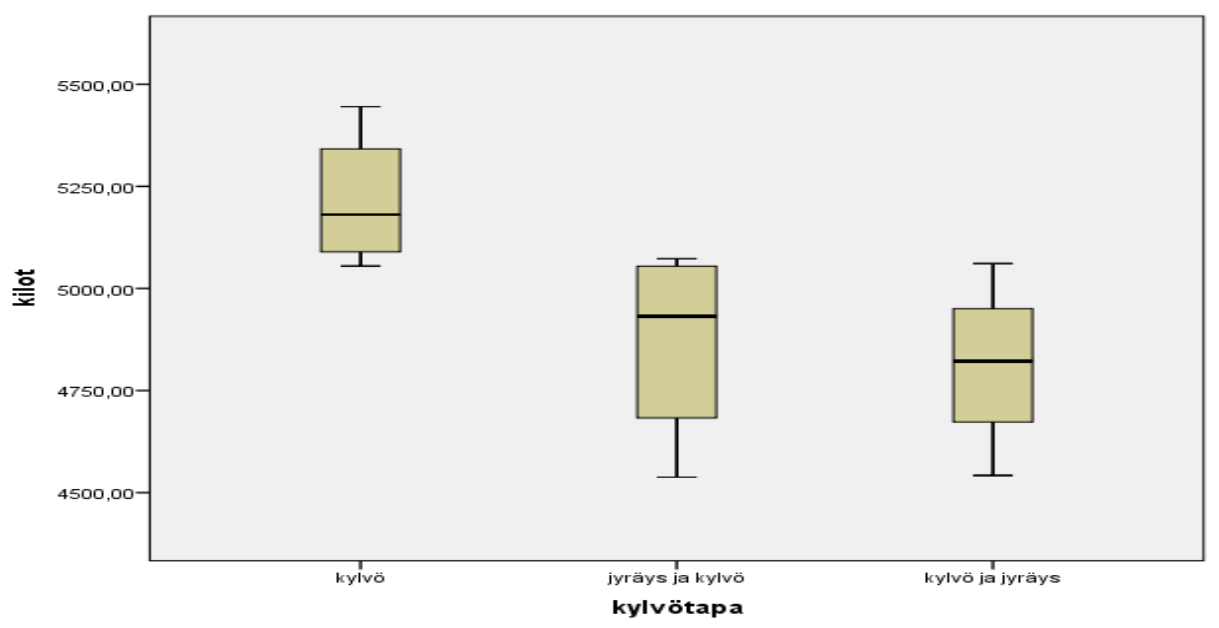

Kuva 5. V 2004 koejäsenten sadot laatikkojanana. Laatikot ja janat kuvaavat vaihteluväliä. Poikkiviiva on mediaani jakaen keskiosan 50 \% havainnoista ja päissä olevat janat kumpikin $25 \%$ havainnoista ja janojen päät vastaavat suurinta ja pienintä havaintoa (Satoero Kylvön ja jyrättyjen välillä on merkitsevä *. SPSS-ohjelma).

Vuonna 2013 jyräykset eivät laskeneet satoa tulos oli yhtenevä Vakolan (savimaa v. 1993) kokeen kanssa (Mikkola 1994, 1995). Vuonna 2014 satotasot laskivat joka oli yhtenevä Vakolan v. 1994 kokeen kanssa (sadetettu liettävästi ennen taimettumista). Vakolan v.1994 kokeessa arveltiin, että aleneminen ei johtunut kuorettumisesta, koska maa pysyi toistuvien sadekuurojen ansiosta pehmeänä vielä pitkään 
orastumisen jälkeenkin. Todennäköisimpänä syynä satoeroon Vakolan kokeessa pidettiin satunnaisvaihtelu, mutta on myös mahdollista, että tiivistäminen on haitannut maan kaasunvaihtoa ja juurten kasvua sateisena keväänä (Mikkola 1995). Tämä voi olla mahdollista, sillä Harmanen (2007) havaitsi Ilmajoen koelohkolla satotason alenevan $25 \mathrm{~kg} / \mathrm{ha}$ jokaista alkukesän (toukokuu-kesäkuu) lisäsademillimetriä kohden välillä $57-160 \mathrm{~mm}$, johtuen mahdollisesta maaperän hapettomuudesta ja/tai ravinteiden huuhtoutumisesta.

Ilmajoen kokeessa v. 2014, satotaso laski jyräyksien johdosta n $500 \mathrm{~kg} / \mathrm{ha}$ ja ero oli tilastollisesti merkitsevä (*) (kuva5). Mikkolan (1994) mukaan jyrätyn hiesu- tai savimaan kuorettumiseen on syytä varautua, vaikka sitä ei heidän kenttäkokeissa tapahtunutkaan. Köylijärven (1989) mukaan jyräyksen vaikutus Ylistaron HHt ja HtS malla on vaikuttanut rypsisato sekä negatiivisesti, että positiivisesti, joten keskimäärin vaikutus oli vähäinen. Piensiemeninen rypsi vaatii hienon kylvöalustan. Hyvin soveltuvalla minipiikkiäkeellä alustasta tulee herkästi liettymä- ja kuorettuma-altis. Esalan ja Hautalan (1981) mukaan jyräyksellä on ollut vuosien 1973-1979 kylvö-tekniikkakokeissa Ylistaron savimailla positiivinen vaikutus, varsinkin kuivina keväinä ja kylvön ollessa myöhäinen, sen sijaan märkään maahan kylvettäessä välitön jyräys on alentanut satoa. Kyseisessä kokeessa ei raportoitu liettymistä eikä kuorettumista.

Vanhoista jyräysmenetelmistä jyräpyörien käyttö on ollut savimailla (Kara ym. 1972) mukaan jonkin verran muita menetelmiä parempi. Kuorettumaan taipuvilla hiesu- ja hiesusavimaila jyräys on syytä suorittaa harkiten ja Karan ym. (1973) mukaan jyräpyörästön käyttö on ollut kylvöä edeltänyttä tai seurannutta kokopinnan jyräystä edullisempi.

\section{Johtopäätökset}

Muokkauksen ja kylvötekniikan tehostuessa ja nopeutuessa jyräyksen merkitys muokkaus ja kylvövirheiden korjaamiseksi on vähentynyt. Kylvökoneista on saatu kapeampia ja paremmin teille mahtuvia sijoittamalla pyörät taakse.

Nykyiset tehokkaat paripyörälliset vetokoneet ja takapyöräkylvökonet muokkaavat ja jyräävät maata tehokkaasti. Tehokkailla koneilla kylvö tapahtuu usein optimioloissa, eikä maa ole kuivaa ja kokkareista. Muruja rikkova vaikutus on siksikin suurempi kuin perinteisillä jyrillä vanhoissa kylvö ja jyräyskokeissa.

Ilmajoen kokeiden perusteella helposti liettyvien ja kuorettuvien kevyiden kivennäismaiden kylvömuokkauksessa on varottava liikaa hienontamista, monesti yksi äestyskerta riittää. Maalajien ominaisuuksien tunteminen ja viljelytekniikan sopeuttaminen vallitseviin ja ennakoitaviin säävaikutuksiin on perusteltua. Tehdyn havaintojen perusteella jyräkylvölannoittimen jyräävät pyörät hienontavat maata ja lisäävät liettymäriskiä sijaitsevatpa jyräpyörät sitten koneen takana takapyöräkone tai sitten ennen kylvövantaita.

Liettymiskokeen tekeminen on ongelmallista. Vakolan kokeessa 1994 savimaalla liettyminen aiheutettiin sadettamalla. Tässä kokeessa oltiin luonnon sateiden armoilla. Kaikissa kokeissa liettyminen toteutui ja kuorettuminen havaittiin. Sateisten säiden johdosta kuorettumisenhaitat koejäsenten sadoissa jäivät v 2013 olemattomiksi, mutta olivat kuitenkin v. 2014 merkitseviä. Helposti liettyvillä ja kuorettuvilla mailla on varottava liian hienoa kylvömuokkausta käytettäessä takapyörökylvökonetta. Mielenkiintoista olisi ollut nähdä olisiko kuorettuman rikkominen pensastumisen alkuvaiheessa vaikuttanut satotasoon. Mikkolan (1994) mukaan Kuorettuman rikkominen on kannattavaa ja paras väline kuorettuman rikkomiseen on tiheäpiikkinen S-piikkiäes. Kokemusten perusteella kevyemmillä mailla kuorettuman rikkomiseen saattaa riittää kamriikkijyrä, varpajyrä tai jopa rikkaäes. 


\section{Kirjallisuus}

Esala, M. ja Hautala, J; 1981: Muokkaus, kylvösiemenen laatu ja kylvötekniikka kevätviljoilla. Maatalouden tutkimuskeskus, Etelä-Pohjanmaan Koeasema Tiedote N:o 4. Ylistaro 1981 ISSN 0358-0385

Harmanen, H. 2007. Sulfaattimaat ja seleeni. Lisensiaatintutkimus. Helsingin yliopisto soveltavan biologian laitos. Julkaisu n:o 33. ISBN 978-952-10-3470-1 (nid.), verkkojulkaisuna 978-952-10-3471-8, PDF

Hannula, V. 2015. Eriaikaiset jyräykset kylvössä, Vaikutus ohran sadon laatuun ja määrään. AMK Opinnäytetyö. (Verkkojulkaisu http://www.theseus.fi/handle/10024/99467)

Kara,O. Räisänen, L, ja Palomäki, A. 1972. Kylvö ja kylvökoneet.

Vakolan tiedote 20/72. (Eripainos koneviesti 8/72)

Kara, 0., Räisänen, L. ja Hänninen, M. 1973. Kevätkylvöjen jyräys. Vakolan tiedote 22/73

(Eripainos koneviesti 9/73)

Köylijärvi, J. 1989: Kevätöljykasvien kylvömuokkaus ja kylvö, s. 11-37 : Teoksessa Öljykasvien viljelyn edistäminen, yhteistutkimuksen tuloksia vuosilta 1985-1988 : MTTK Maatalouden tutkimuskeskus Tiedote 11/89, Jokioinen 1989

Mikkola, H. 1994. Käyttökokemuksia jyräkylvölannoittimista. Maatalouden tutkimuskeskus, Vakolan tiedote 67/94, 17 s. ISSN 0355-1415

Mikkola, H. 1995. Käyttökokemuksia jyräkylvölannoittimista. Koneviesti 43 5/95 s 8- 10

Satotilastot 2014. [Verkkojulkaisu]. [Viitattu 29.8.2015]. Saatavana: http://stat.luke.fi/satotilasto

Simojoki, P. ja Sunio, T. 1979: Hiesun viljelytekniikka. Maatalouden tutkimuskeskus, Keski-Suomen Koeasema Tiedote N:o 3 